補緅誌, J Jpn Prosthodont Soc, $32:$ 137〜150, 1988.

\title{
接着試験法に関する基礎的研究
}

\author{
西島 奉一 新谷 明喜 横塚 繁雄
}

\section{Basic Studies on the Testing Method of Adhesives}

Tomokazu Nishijima, Akiyoshi Shinya and Shigeo Yokozuka

\begin{abstract}
Four different types of methods for testing adhesives for binding to 18-8 stainless steel (SUS 304) were performed using two kinds of dental adhesives, Panavia EX (PE) and Superbond C \& B (SB), and the coefficient of variation (CV\%) of the values determined and the destructive mode were compared among the testing methods.

Furthermore, using the Type III method with high reproducibility that produced a lower coefficient of variation and surface destruction among the above testing methods, the effect of surface treatment on the bond strength was studied, and the following results were obtained.

1. When the bond strength was compared according to the coefficient of variation, it was low for both PE and SB when testing method Type III or IV was used, revealing that they produced little variation.

2. Evaluation of the effect of surface treatment using method Type III which induced surface destruction revealed that the bond strength of PE was increased by ca. $50 \%$ by sand-blast treatment or silane-coupling treatment, and that Sn-electro deposition had no effect.

3. There was no difference in the bond strength of $\mathrm{SB}$ due to sand-blasting or silanecoupling treatment as forms of surface treatment, but the strength was decreased by Sn-electro deposition.
\end{abstract}

Key words : testing method of adhesives, bond strength, adhesive resin, surface processing, wetting characteristics

\section{I. 緒 言}

接着性レジンを応用した歯科臨床例が年々増加してい る. 補緅領域でも接着を応用した臨床術式が広く行われ るようになった. 歯科用接着剤は, 従来の合着用セメン

日本歯科大学歯学部歯科補緅学教室第 2 檴座 (主任: 横塚檠 雄教授)

Department of Crown and Bridge, School of Dentistry at Tokyo, The Nippon Dental University (Chief : Prof. Shigeo Yokotzuka)

昭和 62 年 10 月 5 日受付
卜と異なり，歯質および合金に対して化学的接着力を有 しているので，嵌合効果を得るための広範囲に及ぶ歯質 の削除を必要とせず, 従来の支台歯形成理論にとらわれ ない補緅物の設計が可能となった。 しかし接着力のみに よって維持させている補緅物は，脱離を生じることがあ り，これが現在臨床上の大きな問題になっている. した がって，接着補緅物が咬合その他の応力に対して十分な 強度を持っためには，接着補緅物に加わる応力とそれに 対する接着強度や接着界面における破壊挙動などを把握 することが必要であろう.

接着補緅物の接着界面には, 主に引張応力とせん断応 
表 1 実験 I， II に使用した接着剤

\begin{tabular}{|c|c|c|c|}
\hline xーカー & 商品名 & Lot No. & 略 \\
\hline \multirow[t]{2}{*}{ クラレ } & \multirow[t]{2}{*}{ パナピア EX } & ポリマー PN-0383 & \multirow[t]{2}{*}{$\mathrm{PE}$} \\
\hline & & $\begin{array}{lrr}\text { モノマー } & \text { PL } 224 \\
\text { ポリマー } & 50801\end{array}$ & \\
\hline \multirow[t]{2}{*}{ サンメディカル } & スーパーボンドC \& B & モノマー & \multirow[t]{2}{*}{$\mathrm{SB}$} \\
\hline & & キャタリスト． 526 & \\
\hline
\end{tabular}

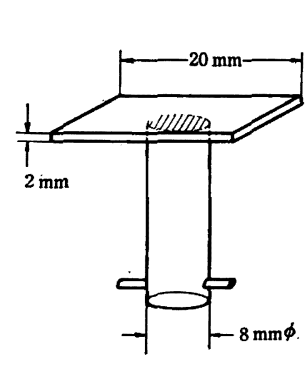

TYPE I

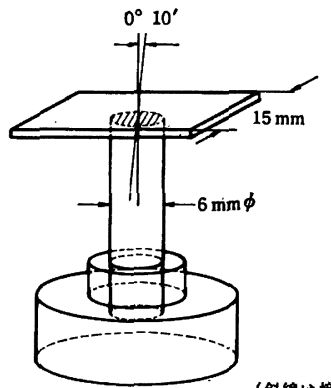

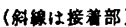

TYPE I

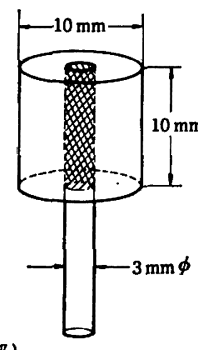

TYPE I

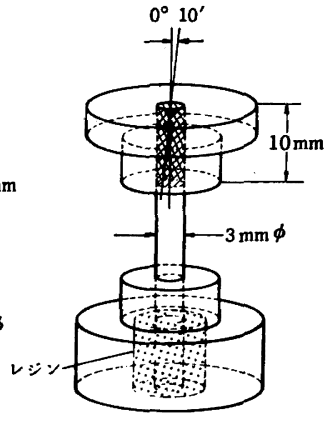

TYPE N

図 1 TYPE I, II, III, IV 試験片の形態

力が作用し，それらによって破壊が生じるものと思わ れ，これまでの接着研究報告も引張試験およびせん断試 験を用いたものが大部分である ${ }^{11}$ 。しかし，歯科領域で は，接着試験方法に関する接着条件・接着環境・測定条 件等の規格化が行われていないために，研究者によって 測定方法が異なりこれらの測定值を単純に比較すること が難しい.さらに接着試験の特性として，接着試験方法 は接着系の破壊という過程で接着強さを評価するため に, 接着片, 被着体, 接着条件など, 多くの因子が交絡 するため, 不可避的な誤差が測定值に関与して測定値が バラッキやすく，実験結果をそのまま臨床に結び付ける のが難しく,これが接着補綴を行う上で安全性を把握で きず臨床応用を躊躇させる原因の 1 つであった. したが って，精度の高い試験方法を開発することにより，界面 における正確な接着强さおよび表面処理の効果が解析で きれば，臨床応用の指標になると考える.

以上のような観点から, 本研究では接着結合部の接着 強さを追求するのではなく，再現性があり精度の高い接 着試験方法を確立することを目的として実験を行った。 実験 Iでは，代表的な試験方法である引張試験とせん断 試験の中から， 2 種類ずつ, 計 4 種類の試験形態を考 案, 作製してバラッキの少ない実験方法について比較検 討し，実験 IIでは，実験 I より選択した検出力の高い試
験方法を用いて，ニッケルクロム合金に対する表面処理 方法の接着強さに及ぼす影響について検討を行った.

\section{II. 実験材料と方法}

実験 I の計画では，2 種類の歯科用接着剂にて形態の 異なる 4 種類の試験方法を用いて，接着強さおよび破壊 形態を求めどの試験方法が最適であるかを比較検 討し た.

実験 II の計画では，実験 I によって確立された界面破 壊を生じる試験方法を用い，合金の表面処理の影響を調 べた.

\section{1. 実 験 I}

1) 実験材料

実験 I に使用した接着剤は，リン酸エステル系接着剤 パナビア $\mathrm{EX}$ (以下 $\mathrm{PE}$ と略す) と, 4-META 系接着凧 スーパーボンド C \& B (以下 SB と略す) の 2 種類で, 被着材料には，18-8 ステンレス鋼（SUS 304）を使用し た. 2 種類の接着鼡のロットナンバーを表 1 に示した.

2）実験 Iにおける試験片の形態および実験方法 実験 I に用いた試験片の形態は，図 1 に示した TYPE I, TYPE II, TYPE III, TYPE IV の 4 種類である. TYPE 
I の試験方法は接着界面に垂直な応力の加わる引張試験 法である. 被着材料汇は縦 $20 \mathrm{~mm}$, 横 $15 \mathrm{~mm}$, 厚さ 2 $\mathrm{mm}$ の SUS 304 製の板状試験片と, 外径 $8 \mathrm{~mm}$, 内径 6 $\mathrm{mm}$, 長さ $20 \mathrm{~mm}$ の端面が平行加工されたアルミニウム 製円筒試験片を用いた. 試験片保持部は試験片の軸に垂 直になるように, 直径 $3 \mathrm{~mm}$ の孔を部から $3 \mathrm{~mm}$ の位 置にあけ, 直径 $2.5 \mathrm{~mm}$, 長さ $12 \mathrm{~mm}$ のロッド鋼を即時 重合レジンにて固定した. TYPE II は TYPE I と同様 の試験方法であるが, JIS K-6849 に規定されている引張 方向の接合公差が $0^{\circ} 10^{\prime}$ 以内におさまるよう設計した 接着ジグおよび試験片保持部を持つ形態である. 被着材 料の板状試験片は TYPE I と共通のものを使用し, 円筒 試験片は SUS 304 製で外径 $6 \mathrm{~mm}$, 内径 $5 \mathrm{~mm}$ の内部に ネジ山によるアンダーカットが付与された試験片を用い た. 試験片保持部は円筒試験片にネジ止めされるように なっている. TYPE III, TYPE IV は接着界面に平行な応 力の加わる引抜き試験法である. TYPE III は岩間が行っ た陶材の焼付强さの研究2)に用いた引抜き法を接着試験 用に改良したもので，界面にせん断応力を加える方法で ある. 被着材料は直径 $3 \mathrm{~mm}$ 長さ $30 \mathrm{~mm}$ の SUS 304 製 円柱状試験片を用い接着剤基底部に厚さ $1 \mathrm{~mm}$ のエルコ レンシートを敷き, 接着面全体に均一な荷重が加わるよ うにして測定を行った. つかみ部は被着材料を直接取付 具にチャッキングする形態とした. TYPE IV の被着材料 は TYPE III と共通のものを使用し，接着剂層が $50 \mu \mathrm{m}$ と一定な厚さになるよう調整され,より臨床に近い条件 となっている. また, 接着ジグ, 試験片保持部装着用ジ グ, 試験片保持部を付与することにより試料を接合公差 $0^{\circ} 10^{\prime}$ 以内に接着し，また直接保持できないセラミック スなどのぜい性材料に対する接着試験に応用できる形態 としたものである.

\section{3）試験片の作製}

$\mathrm{PE}, \mathrm{SB}$ 共に, それぞれの実験方法に対する必要量を メーカー指定粉液比にて計量し接着試験を行った.

TYPE I, TYPE II の試験片は, PE ではポリマーを計量 カップ大 1 杯, モノマー2 滴とり付属の練和紙にて 90 秒間練和し，接着面積が一定となるように，マスキング テープを介して接着を行った. 接着後直ちに余剩部分を 除去し，オキシガードを塗布して硬化させた．SB では 付属のダッペングラスにモノマー8滴をとり，その中に キャタリスト 2 滴を滴下し罍拌後, 筆を用い被着材料に 活性化されたモノマーを塗布してから筆積法にて，マス キングテープを介して接着し余剩部分を除去した. TYPE II は接着に際し, 図 2 に示した接着ジク゚を用い

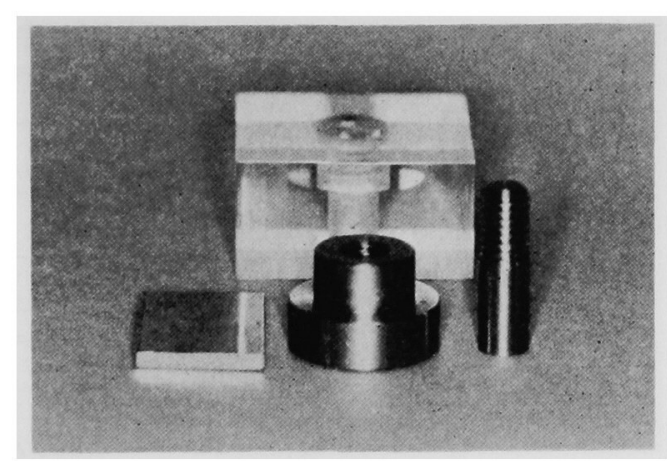

図 2 TYPE II 接着用ジグ

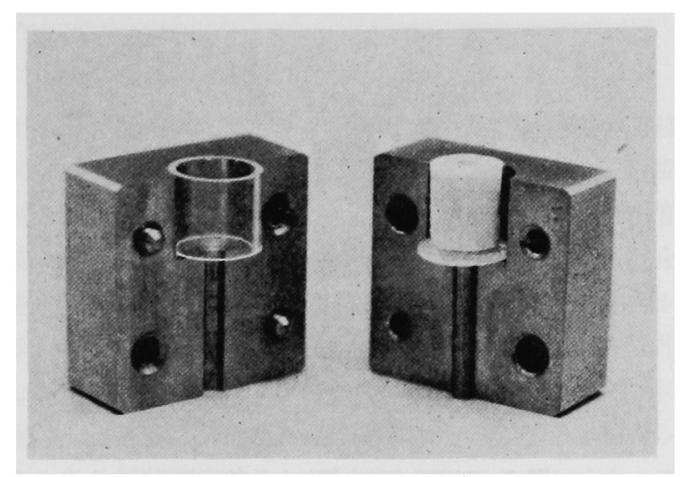

図 3 TYPE III 填入用二分割金型

て被着面と垂直になるよう調整し割裂の影響を少なくし た.

TYPE III の試験片は, 図 3 に示した二分割嵮入金型を 用い, 金型の溝の部分に被着材料を入れ，マトリックス として底面にビニールシートを敷き，側面にビニールチ ユーブを入れて填入を行った. 接着剤は，PE ではポリ マーを計量カップ大 6 杯 $(1.3 \mathrm{~g})$ ，モノマー 12 滴をとり， 実験 I と同一条件化て練和後バイプレーター上で金型内 に填入し，ガラス練板上に $150 \mathrm{~g}$ の荷重をかけ，金型と ガラス練板の境界にオキシガードを塗布して嫌気性雾囲 気とした状態で硬化させた. SB ではモノマー20滴, キ ヤタリスト 5 滴を使用して TYPE I と同一条件にてバイ プレーターを用いて筆積法で填入を行った，すべての試 験片は 30 分室温中に放置後, $37^{\circ} \mathrm{C}$ 水中に 24 時間保存し て測定を行った. TYPE IV の試験片は, TYPE I, TYPE I試験片作製時に使用した接着剂と同量の接着剂を用 い, 被着材料が下部つかみ部と $50 \mu \mathrm{m}$ の均等なセメン 卜厚さにて垂直になるよう図 4 に示した接着ジグを用い て接着した，接着後の試験片は，上部つかみ部を図 5 に 示した上部つかみ部装着ジグにて即時重合レジンを用い て装着した．接着後の TYPE I, II, III, IV 試験片を図 6 


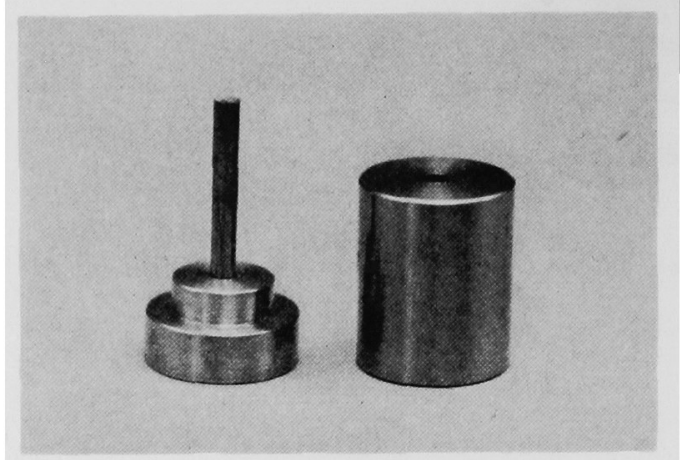

図 4 TYPE IV 接着用ジグ

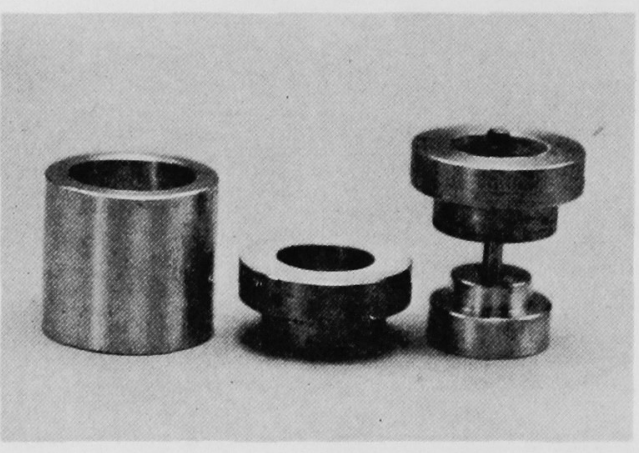

図 5 TYPE IV 上部つかみ部装着ジグ

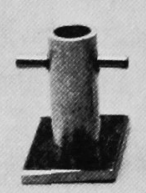

I

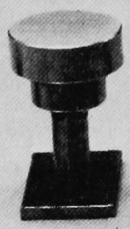

I.I

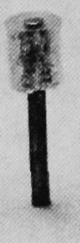

111

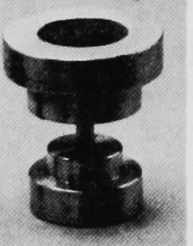

IV
図 6 TYPE I, II，III, IV の接着後の試験片

に示す.

4）接着強さの測定方法

接着強さの測定には，島津社製万能試験機 IS 5000 を 使用し,クロスヘッドスピードは $0.5 \mathrm{~mm} / \mathrm{min}$ と一定に した. 図 7 に示した取付具を用いて荷重をかけると自動 的に位置が調整され，荷重方向が試験片の軸と一致する ようユニバーサルジョイント付のものを使い，金属と接 着界面に純粋な引張応力およびせん断応力が加わる構造 として測定を行った. 接着強さ $\mathrm{S}\left(\mathrm{kgf} / \mathrm{cm}^{2}\right)$ は, 破壊荷 重 P (kgf)を用いて下記の式より算出した.

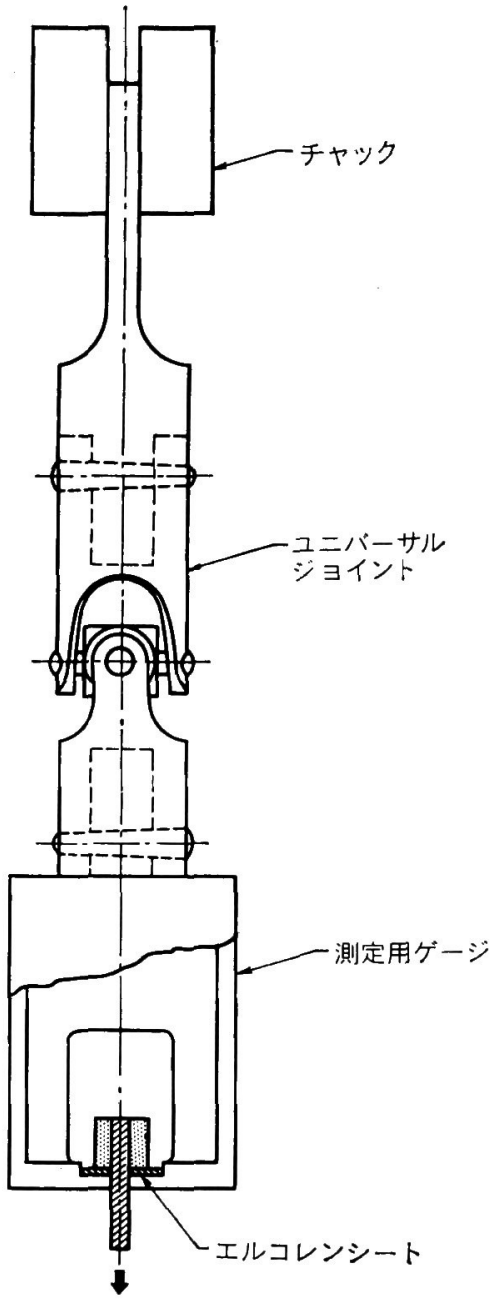

図 7 引抜き試験の模式図

TYPE I, TYPE II

$\mathrm{S}=\mathrm{P} / \pi(\mathrm{d} / 2)^{2}$

$\mathrm{d}:$ 接着剤被着面の平均直径 $(\mathrm{cm})$

TYPE II, TYPE IV

$$
\mathrm{S}=\mathrm{P} / \pi \mathrm{dL}
$$

$\mathrm{d}:$ 被着体の平均直径 $(\mathrm{cm})$

$\mathrm{L}$ : 被着面の長さ $(\mathrm{cm})$

\section{2. 実 験 II}

1）因子と水準

実験 II では，合金表面処理の影響を調べるため，表 2 に示した因子と水準について二元配置による要因配置実 験を行った．因子 A は表面処理で，\#600 耐水研磨紙研 
表 2 実験 II の因子と水準

\begin{tabular}{ccccc}
\hline \hline \multirow{2}{*}{ 子因 } & \multicolumn{5}{c}{ 水 } & 準 & \\
\cline { 2 - 5 } & 1 & 2 & 3 & 4 \\
\hline $\mathrm{A}:$ : 表面処理 & \#00 & サンドブラスト & スズ電析 & シラン \\
$\mathrm{B}:$ 接着郕 & $\mathrm{PE}$ & $\mathrm{SB}$ & & \\
\hline
\end{tabular}

表 3 表面処理の実験に使用した材料

\begin{tabular}{ccc}
\hline \hline メーカー & \multicolumn{1}{c}{ 商品名 } & Lot No. \\
\hline トーワ技研 & SBボンドロイ I & 85168 \\
関東研磨材 & ホワイトパウターWA & 850107 \\
日本アビオニクス & クラエース & 012600 \\
クルツァー & シリコーターシステム & シリフレーム506021 \\
& & シリカッフ 507021 \\
\hline
\end{tabular}

磨処理 (以下 \#600 と略す), $50 \mu \mathrm{m}$ 酸化アルミナサンド ブラスト処理 (以下サンドブラストと略す), スズ電析 処理 (以下スズ電析と略す), シランカップリング 処 理 (以下シランと略す) の 4 水準とした. 因子Bは接着剤 の種類で, 実験 I と同様にリン酸エステル系接着剤, 4META 系接着剂の 2 水準とした. また, 実験】に使用 したニッケルクロム合金は SB ボンドロイ I で, 表面処 理法に用いた材料名, メーカーおよびロットナンバーを 表 3 に示した，被着材料表面は，\#600 耐水研磨紙にて 研磨後水洗し, $99 \%$ アセトン, 精製水にてそれぞれ 15 分間ずつ超音波洗浄を行い自然乾燥後実験に供した.

2）実験 Пの試験方法

実験 IIでは, 界面破壊を起こし測定値の最も安定して いた TYPE III 試験方法を用いて, \#600 耐水研磨紙研磨 処理, $50 \mu \mathrm{m}$ 酸化アルミナサンドブラスト処理, スズ電 析処理, およびシランカップリング処理したニッケルク ロム合金の表面処理効果について検討した.

3）実験 II の被着材料作製

a）埋没および鋳造方法

実験 IIに用いる TYPE III の被着材料を作製するため に, 円柱状試験片を $40 \mathrm{~mm}$ に切断し，パラフィンワッ クスで薄くコーティングしたのち, セラベスト（GC 社 製) をメーカー指定の混液比にて, 塩化ビニール製割型 リングを使用し，リングレス埋没を行った．硬化後パタ ーンを引抜き, マイコンファーネス (ユニカ社製)をメ 一カー指定の昇温スケジュールにプログラムして脱ロウ 加熱を行い，アルゴンキャスター（松風社製）を用いて ニッケルクロム合金の鋳造を行った. 表面清浄, 研磨は 実験 I と同一条件とした.

b) 表面処理

\#600 耐水研磨紙研磨面を基準面として各処理は重複
することなく施した. サンドブラスト処理は, 平均粒度 $50 \mu \mathrm{m}$ の酸化アルミナ粒を $3 \mathrm{kgf} / \mathrm{cm}^{2}$ の圧力で 30 秒間 被着材料に垂直に $10 \mathrm{~mm}$ の距離にて行い, 15 分間超音 波洗浄した. スズ電析処理は, クラエースのモード 2 を 選んで電析し, その後, 5 分間精製水にて洗浄した. シ ランカップリング処理は, シリコーターシステムを使用 して円柱試験片をホルダーにて火炎反射リングと平行に 保持し, 表裏 2 分間ずっ被着面にテトラエトキシシラン を火炎分解蒸着処理し, 5 分間冷却してからシリカップ を筆にて塗布し接着を行った.

\section{III. 実験結果}

\section{1. 実験 I の接着強さ測定結果}

接着剤に $\mathrm{PE}, \mathrm{SB}$ を用いたときの接着強さの平均値, 不偏分散, 標準偏差 $95 \%$ 信頼区間, 変動係数を TYPE 別に表 4 に示した. また平均值と標準偏差をグラフ化し 図 8 に示した.PE を用いたときの接着強さの平均值は, TYPE II の接着ジグを用いた引張強さ測定法を利用し た方法の場合最大で $139 \mathrm{kgf} / \mathrm{cm}^{2}$, TYPE I の接着ジグを 用いない引張強さ測定法を利用した方法の場合 最小で $89 \mathrm{kgf} / \mathrm{cm}^{2}$ であった. SB を用いたときの TYPE IV の引 抜きせん断法の場合最大で $363 \mathrm{kgf} / \mathrm{cm}^{2}$, TYPE II の接 着ジグを用いた引張強さ測定法を利用した方法の場合最 小で $183 \mathrm{kgf} / \mathrm{cm}^{2}$ であった. 各試験方法の変動係数をグ ラフ化し図 9 に示す. PE を用いたときは TYPE I の場 合最大で 18.9 (\%), TYPE III が最小で 6.2 (\%) であ り, SB を用いたときには TYPE II が最大で 13.5 (\%), TYPE IV が最小で 2.7 (\%) であった. PEの測定值の不 偏分散は, 平均值と同様に TYPE II が最大で 517 (Kgf/ $\left.\mathrm{cm}^{2}\right)^{2}$, TYPE III が最小で $78\left(\mathrm{kgf} / \mathrm{cm}^{2}\right)^{2}$ である. SB を 
表 4 各試験方法の測定値 $\left(\mathrm{kgf} / \mathrm{cm}^{2}\right)$

\begin{tabular}{rrrrrrrrr}
\hline \hline & \multicolumn{2}{c}{ Type I } & \multicolumn{2}{c}{ Type II } & \multicolumn{2}{c}{ Type III } & \multicolumn{2}{c}{ Type IV } \\
\cline { 2 - 9 } & \multicolumn{1}{c}{ PE } & \multicolumn{1}{c}{ SB } & \multicolumn{1}{c}{ PE } & \multicolumn{1}{c}{ SB } & \multicolumn{1}{c}{ PE } & SB & PE & SB \\
\hline 1 & 61 & 178 & 156 & 150 & 133 & 265 & 105 & 354 \\
2 & 110 & 243 & 120 & 212 & 115 & 266 & 121 & 380 \\
3 & 78 & 231 & 105 & 213 & 137 & 274 & 110 & 357 \\
4 & 92 & 235 & 146 & 155 & 124 & 276 & 127 & 353 \\
5 & 84 & 215 & 166 & 186 & 136 & 282 & 129 & 365 \\
6 & 106 & 181 & 141 & 181 & 136 & 248 & 128 & 370 \\
\hline $\bar{X}$ & 89 & 214 & 139 & 183 & 130 & 269 & 120 & 363 \\
V & 334 & 791 & 517 & 725 & 78 & 142 & 104 & 112 \\
SD & 16.7 & 25.7 & 20.8 & 24.6 & 8.1 & 10.9 & 9.3 & 9.7 \\
Qi & \pm 19.2 & \pm 29.5 & \pm 23.9 & \pm 28.3 & \pm 9.1 & \pm 12.6 & \pm 10.6 & \pm 11.3 \\
CV & 18.9 & 12.0 & 14.9 & 13.5 & 6.2 & 4.0 & 7.8 & 2.7 \\
\hline
\end{tabular}

表 5 分散比 $\mathrm{F}_{0}$ と検定結果

\begin{tabular}{ccccccc}
\hline \hline 接着剂 & & TYPE I & TYPE II & TYPE III & TYPE IV & 接着剤 \\
\hline \multirow{4}{*}{ PE } & TYPE I & & 1.05 & 5.53 & 6.82 & \\
& TYPE II & 1.54 & & 5.08 & 6.27 & SB \\
& TYPE III & 4.46 & 6.88 & & 1.23 & \\
& TYPE IV & 3.32 & 5.11 & 1.34 & & \\
\hline
\end{tabular}

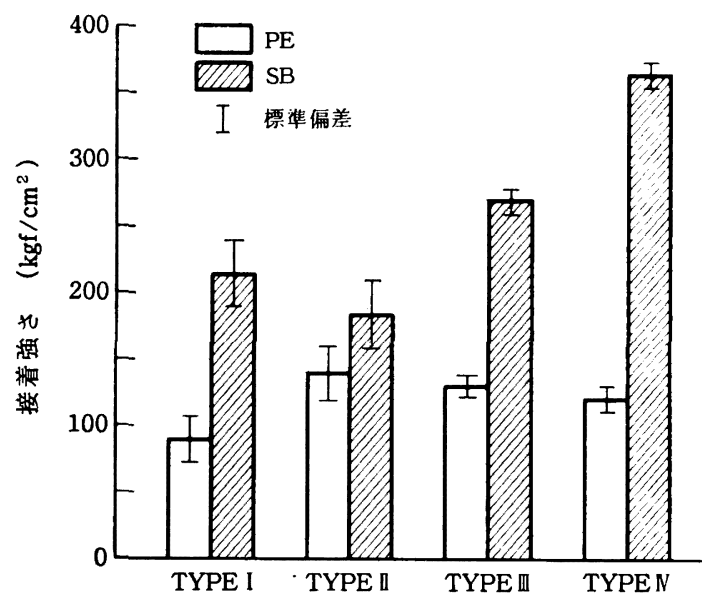

図 8 実験 I 試験方法に対する接着強さ

用いたときは, TYPE I が最大で $791\left(\mathrm{kgf} / \mathrm{cm}^{2}\right)^{2}$, TYPE IVが最小で $112\left(\mathrm{kgf} / \mathrm{cm}^{2}\right)^{2}$ である. 測定值の不偏分散に 有意な差があるかどうかを調べるため, 分散比の検定を 行った. すなわち, 水準 1,2 の不偏分散をそれぞれ $\mathrm{V}_{1}$, $\mathrm{V}_{2}$ とし, $\mathrm{V}_{2}>\mathrm{V}_{1}$ ならば, 分散比 $\mathrm{F}_{0}$ は $\mathrm{F}_{0}=\mathrm{V}_{2} / \mathrm{V}_{1}$ で, これを有意水準 $\alpha / 2$ で検定した. 検定結果は表 5 のとお りである. 危険率 $\alpha=0.05$ のとき両側検定における F 値は 7.15 であるから, 計算された $\mathrm{F}_{0}$ 値は, いずれも $\mathrm{F}$ 値 7.15 よりも小さく, 各 TYPE 間の不偏分散に差があ

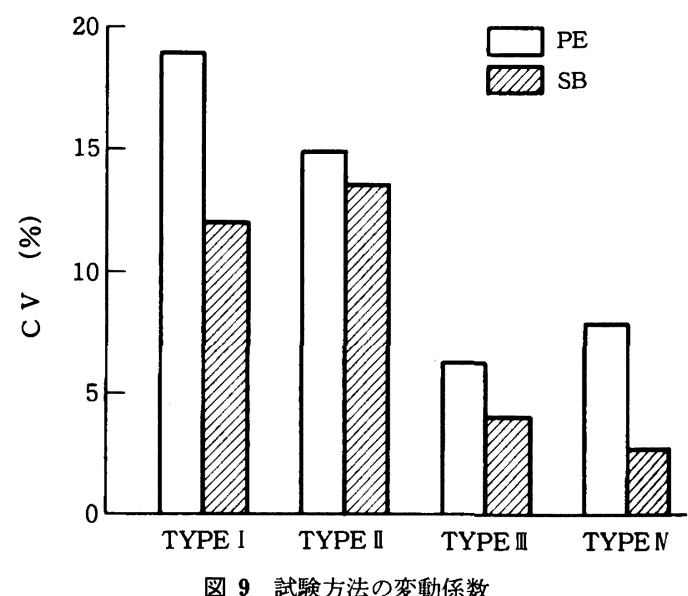

るとはいえない. すなわち, TYPE I と TYPE II はバラ ツキはかなり大きいが, 統計的に差があるとはいえな い. つぎに分散の違いがないと考えて, 統計量 $\mathrm{t}_{0}$ を求 め, 計算された $\mathrm{t}_{0}$ と $\mathrm{t}(10.0 .01)=3.169$ を比べ $\mathrm{t}_{0} \geqq \mathrm{t}_{1}$ ならば, $\mathrm{H}_{0}: \overline{\mathrm{x}}_{1} \mathrm{t}_{0} \geqq \mathrm{t}_{1}$ ならば, $\mathrm{H}_{0}: \overline{\mathrm{x}}_{1}=\overline{\mathrm{x}}_{2}$ を棄却する平 均値の差の検定を行った. 検定結果は表 6 のとおりであ る.

危険率 $\alpha=0.01$ の 值は 3.169 であるから, PE の平 均値の差は, TYPE I と TYPE II, III, IV において高度に 有意となり, SB の平均值の差は, TYPE I と TYPE II 
表 6 平均値の差の検定 ( $\left.t_{0}\right)$

\begin{tabular}{ccccccc}
\hline \hline 接着剂 & & TYPE I & TYPE II & TYPE III & TYPE IV & 接着剤 \\
\hline \multirow{4}{*}{ PE } & TYPE I & & 1.95 & $4.38^{* *}$ & $12.17^{* *}$ & \\
& TYPE II & $4.22^{* *}$ & & $7.13^{* *}$ & $15.27^{* *}$ & SB \\
& TYPE III & $4.68^{* *}$ & 0.84 & & $14.57^{* *}$ & \\
& TYPE IV & $3.69^{* *}$ & 1.87 & 1.34 & & \\
\hline
\end{tabular}

** 信頼率 $99 \%$ で有意

表 7 実験 II の測定値 $\left(\mathrm{kgf} / \mathrm{cm}^{2}\right)$

\begin{tabular}{|c|c|c|c|c|}
\hline \multirow{2}{*}{ 接着剤 } & \multicolumn{4}{|c|}{ 表面処理 } \\
\hline & $\begin{array}{c}\text { \#600 } \\
\text { 酎水研磨紙 }\end{array}$ & $\begin{array}{c}50 \mu \mathrm{m} \\
\text { サンドブラスト }\end{array}$ & スズ電析 & $\begin{array}{c}\text { シラン } \\
\text { カッナリリンク }\end{array}$ \\
\hline \multirow{4}{*}{$\begin{array}{c}\text { ハナピア } \\
\mathrm{EX}\end{array}$} & 101 & 142 & 99 & 139 \\
\hline & 99 & 143 & 118 & 149 \\
\hline & 99 & 136 & 89 & 161 \\
\hline & 89 & 132 & 103 & 150 \\
\hline \multirow{4}{*}{$\begin{array}{c}\text { スーハーーボンド } \\
\text { C\&B }\end{array}$} & 215 & 187 & 77 & 236 \\
\hline & 190 & 216 & 77 & 209 \\
\hline & 195 & 202 & 75 & 206 \\
\hline & 210 & 193 & 74 & 251 \\
\hline
\end{tabular}

表 8 実験 II の分散分析法

\begin{tabular}{crrrr}
\hline \hline 要 因 & \multicolumn{1}{c}{ ss } & df & \multicolumn{1}{c}{ ms } & \multicolumn{1}{c}{ Fo } \\
\hline $\mathrm{A}$ : 表面処理 & 43899 & 3 & 14633 & $110.86^{* *}$ \\
$\mathrm{~B}:$ 接着風 & 23328 & 1 & 23328 & $176.73^{* *}$ \\
$\mathrm{~A} \times \mathrm{B}$ & 19316 & 3 & 6439 & $48.77^{* *}$ \\
$\mathrm{e}$ & 3168 & 24 & 132 & \\
\hline $\mathrm{T}$ & 89711 & 31 & & \\
\hline
\end{tabular}

**信頼率 $99 \%$ で有意

表 9 平均値の差の検定 $\left(\mathrm{q}_{0}\right)$

\begin{tabular}{ccccccc}
\hline \hline 接着削 & & $\mathrm{A}_{1}$ & $\mathrm{~A} \mathrm{~A}_{2}$ & $\mathrm{~A}_{3}$ & $\mathrm{~A}_{1}$ & 接着㓱 \\
\hline \multirow{4}{*}{$\mathrm{PE}$} & $\mathrm{A}_{1}$ & & 0.42 & $17.75^{* *}$ & 3.22 & \\
& $\mathrm{~A}_{2}$ & $9.82^{* *}$ & & $17.33^{* *}$ & 3.64 & $\mathrm{SB}$ \\
& $\mathrm{A}_{3}$ & 1.25 & $8.57^{* *}$ & & $20.98^{* *}$ & \\
& $\mathrm{~A}_{4}$ & $12.56^{* *}$ & 2.74 & $11.31^{* *}$ & & \\
\hline
\end{tabular}

** 信頼率 $99 \%$ で有意

を除く全ての部位において高度に有意となった.

\section{2. 実験 II : 表面処理の効果}

実験 II の測定值を表 7 に示す．各表面処理の X-R 管 理限界を求め，等分散の検定を行い等分散していること を確認したのち，二元配置分散分析を行った．表 8 に分 散分析表を示す. 表面処理 (因子 A), 接着剤 (因子 B), およびそれらの交互作用効果 $\mathrm{A} \times \mathrm{B}$ すべてが高度に有意

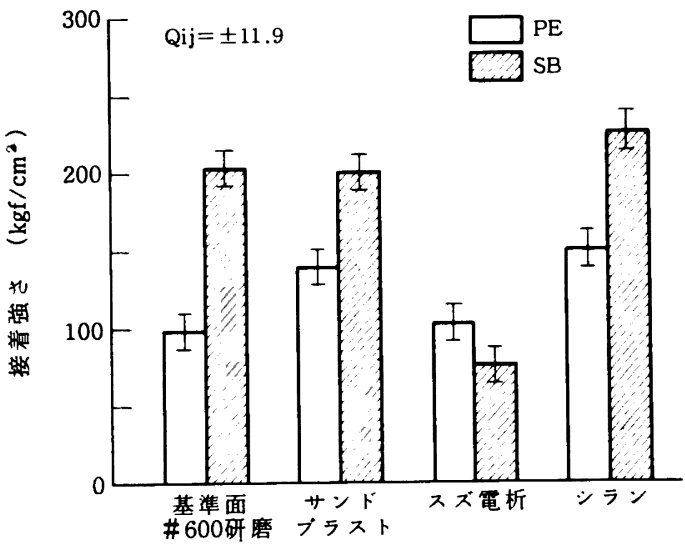

図 10 実験 I表面処理に対する接着強さ

となった．接着剤に $\mathrm{PE}, \mathrm{SB}$ を用いたとき最も効果的な 表面処理方法は，いずれもシランカップリング処理を行 った場合でそれぞれ平均值で $149 \mathrm{kgf} / \mathrm{cm}^{2}, 225 \mathrm{kgf} / \mathrm{cm}^{2}$ の接着強さを示した. 表面処理と接着強さの関係をグラ フ表示し図 10 に示す. $95 \%$ 信頼区間 $\mathrm{Q}_{\mathrm{ij}}$ は $\pm 11.9 \mathrm{kgf} /$ $\mathrm{cm}^{2}$ であった.

スチューデント化された範囲を用いて各水準間の平均 值の差の検定を行い, 統計量 $\mathrm{q}_{0}$ を求め, 計算された $\mathrm{q}_{0}$ と $\mathrm{q}(4,12,0.01)=5.50$ を比べ $\mathrm{q}_{0} \geqq \mathrm{q}_{1}$ ならば, $\mathrm{H}_{0}: \overline{\mathrm{x}}_{1}=$ $\overline{\mathbf{x}}_{2}$ を棄却する平均値の差の検定を行った. $\$ 600$ 耐水研 


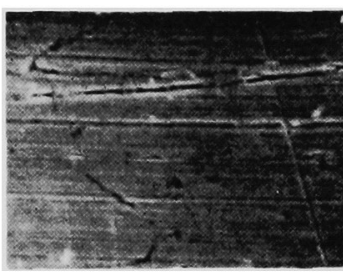

$\# 600$ 研磨

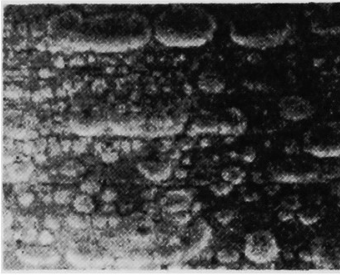

スズ電析処理

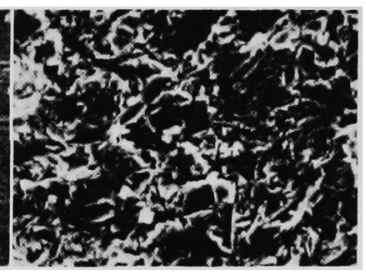

サンドブラスト処理

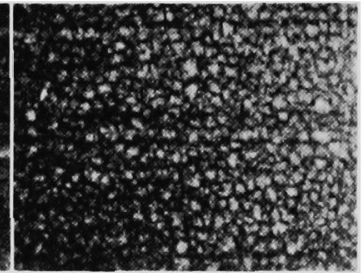

シランカップリング処理

图 11 各表面処理の SEM 像

磨紙研磨面の平均值を $\AA_{1}, 50 \mu \mathrm{m}$ サンドブラスト処理面 の平均值を $\mathrm{A}_{2}$, スズ電析処理面の平均值を $\mathrm{A}_{3}$, シランカ ップリング処理面の平均値を $\AA_{4}$ とした検定結果を表 9 に示した.

危険率 $\alpha=0.01$ の 值は 5.50 であるから，PE の平 均値の差は $\mathrm{A}_{1}$ と $\mathrm{A}_{2}, \mathrm{~A}_{1}$ と $\mathrm{A}_{4}, \overline{\mathrm{A}}_{2}$ と $\bar{A}_{3}, \bar{A}_{3}$ と $\bar{A}_{4}$ に おいて高度に有意となり, $\mathrm{SB}$ の平均值の差は $\AA_{1}$ と $\AA_{3}$, $\mathrm{A}_{2}$ と $\bar{A}_{3}, \bar{A}_{3}$ と $\AA_{4}$ に拉いて高度に有意となった。

\section{SEM 像観察について}

SEM 像による観察を図 11 に示した. \#600 耐水研磨 紙研磨面は，研磨による条痕が平行に一方向に走行して いる. $50 \mu \mathrm{m}$ サンドブラスト処理面は，\#600 耐水研磨 紙研磨による条痕は消失して鋭利な梨状を呈している。 スズ電析処理面は平行な条痕の状態を残しながら，その 上に粒状の電析されたスズが付着している像が観察さ れ，その付着状態は一様ではなく活性点となった条痕や 異物にそってコロニーの上うな多量に付着している部位 が見られる. シランカップリング処理面においても条痕 を残しながらそその上に鋭利な細かい $\mathrm{SiOx}-\mathrm{C}$ 層が一様 に付着している.

\section{IV. 考察}

\section{1．試験方法が接着強さに及ぼす影響}

接着強さとは，接着系の破壊強度により得られる値で あり，多くの因子の影響をうけ本質的にバラッキを持っ 值である．また破壊形態によって，得られた接着強さの
32 巻 1 号 (1988)

力学的意味が違ってくることから, 規格化が必要である と思われる.このような理由から，一般に用いられている 破壊形態の異なる 4 種類の試験方法について検討した.

引張試験方法は, 有効接着面積があまり確保できない 歯牙と接着㓮との接着試験には有効であるが，接着面を 正確に平行加工しないと曲げまたは割裂力が㗢くので， 構造材用の試験方法として用いられることは少ない33. つまり引張試験方法は, その構造から偏曲の可能性を含 んだ試験方法であり，実験の精度をあげることが難 し い.この偏曲を防ぐものとして，特殊な形態も考案され ているが加工が難しく一般的ではない，これに対してせ 儿断試験は，被着面積を自由に設定できることから広く 用いられている. せん断試験には，本研究で TYPE II， TYPE IV に使用した引抜き試験法や, 種々の重ね合わせ 試験法があるが，これらのすべての試験法が均等な応力 分布を持っているわけではなく，例えば単純重ね合わせ 法は，軸線外力の方法と一致しない4) ので，曲げモーメ ントを生じたり，端面に応力が集中しやすい欠点があ る. 上記の欠点を防ぐものとして，二重重社合せ法や管 の重和合せ法が考案され，本研究の TYPE III, TYPE IV は, 二重重权合わせ法や管の重权合わせ法を改良したも のである.

引張試験法は, 有限要素法で調べた結果(5) から, 応力 が不均一になり端面付近で応力集中を起こすことが報告 されている.このことより引張試験法は，試験形態と応 力分布の両面から, 割裂や偏曲が起こりやすい試験法で あるといえる. TYPE I, TYPE II は引張試験法であり， 接着ジグを用いない TYPE I は割裂の影響が強く現れた 結果, 測定值のバラッキが大きくなったものと思われる. また PE はコンポジット系のぜい性材料であるので, 割 裂に伴いクラックが急激に進展し，TYPE I の接着強さ を低下させ TYPE II と平均值の差が生じたものと考え る.したがって,引張方向を $0^{\circ} 10^{\prime}$ 以内になるように規 定した TYPE II の試験片が TYPE I に比べて大きな接 着強さを示したと思われる．一方 SB は線状ポリマー状 に重合しているために弾性を有し，弾性変形をすること により応力緩和が起こり，割裂の影響が現れにくく TYPE I, TYPE II の平均値に差が生じなかったものと 考える.

TYPE III, TYPE IV はせん断試験法で，断面の形態が 近似している 2 重重衫合わせ試験法において，端面にや や応力集中部が認められるものの，単純重ね合わせ試験 法に比べて応力集中が少ない6) ことから，ほぼ均等にせ ん断応力が分布していると考えられる，また野口ら”゙， 


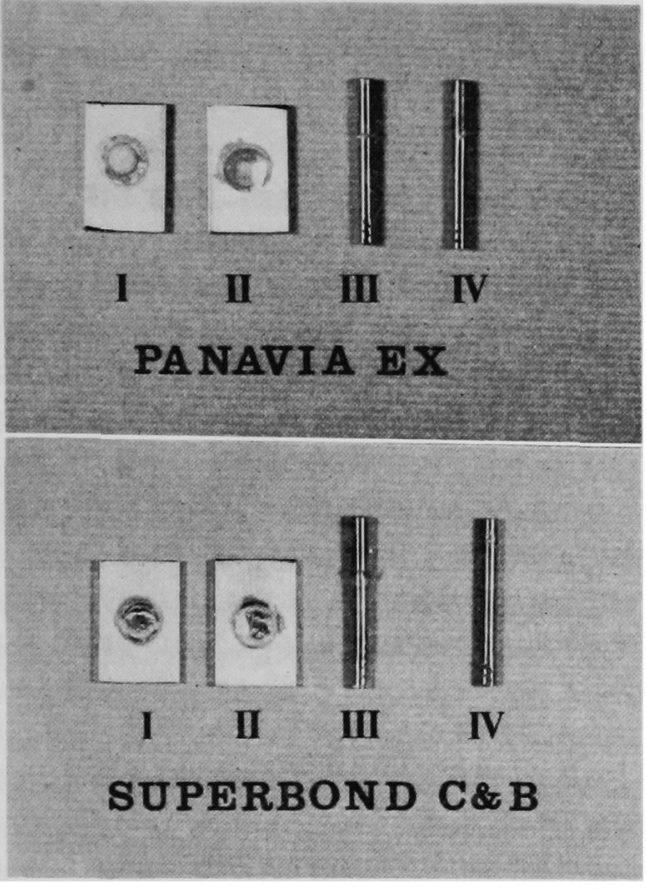

図 12 各試験方法における破壊形態

引張試験法は試験機の引張方向などの微小な違いが, 大 きく結果に影響することが啋念されると報告しており， これらのことから, 試験方法としてせん断試験法自体 が, 引張試験法に比べてバラッキにくいのではないかと 思われる.これは, せん断試験法は力の方向がぜい性で ないことと，接着面積を大きくとれることが主な原因と 考えられる、したがって，接着試験法としてはせん断試 験法が，より安定した試験方法だと思われる. 以上のこ とより, TYPE III, TYPE IV の変動倸数が小さくなった ものと考える.

つぎに TYPE III と TYPE IV の差であるが, PE では TYPE III, TYPE IV がほぼ同じ接着強さを持つのに対 して, SB では TYPE III, TYPE IV で大きく変化した. これは, PE がフィラー含有のコンポジットレジン系接 着剤であるために，接着剂層の厚さの影響を受けにくい のに対して, 線状ポリマーである SB は, 熱田らの報告8) と同様に接着剤層の影響が現れたものと思われる.この 接着剂層の厚さによる影響については，今後解決すべき 問題の 1 つであろう.

\section{2. 接着破壊面による評価}

図 12 に PE, SB の実験 I の破壊形態を示し, 図 13, 14 に各接着剤の破壊形態の比率を示す.試験片の形態か

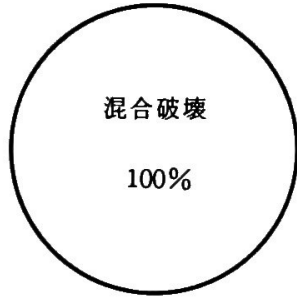

TYPE 1

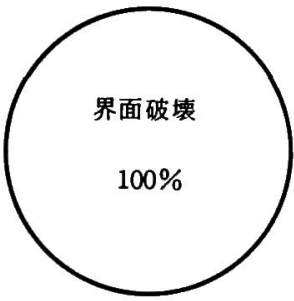

TYPE II

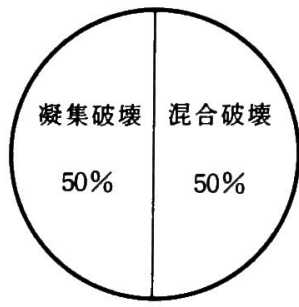

TYPE II

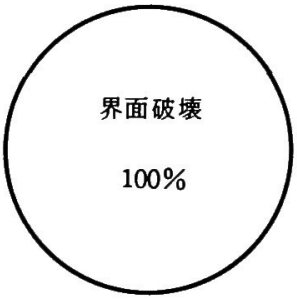

TYPE N
図 $13 \mathrm{PE}$ の破壊形態の比率

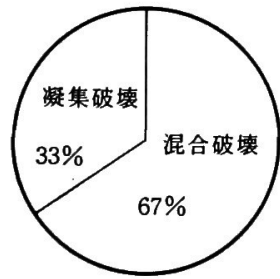

TYPE I

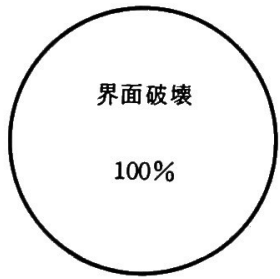

TYPE II

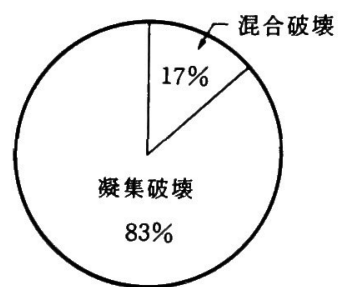

TYPE ॥

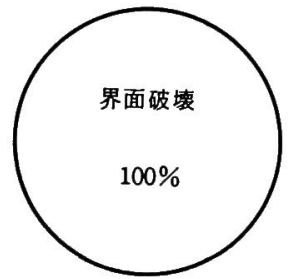

TYPE $N$
図 $14 \mathrm{SB}$ の破壊形態の比率

ら分類すると,

(1) 凝集破壞 (Cohesive Failur CF と略す)

(2) 界面破壊 (Interface Failure IF と略す)

(3) 混合破壊 (CF - IF と略す)

の 3 形態に大きく分けることができ, 接着剤間, 試験片 形態間で特徴的な破壊面をみることができる.すなわち， PE において TYPE I ではすべての試験片で端面付近に IF, 内部に CF の状態となった被着材料上に, 接着昘が 弧状に残留した CF・IF の破壊形態を示した。これは曲 
げモーメントにより端面に応力が集中した結果, PE の ようなぜい性材料ではここから亀裂が生じ接着剤内部に 破壊が進展し破断したものと思われる.TYPE II では CF と IF の比率が $50 \%$ ずっとなり，接着ジグを使用す ることにより応力の集中が少なくなり, 精度が上がった ためと思われる。

SB において，TYPEI では CF・IF が $67 \%$ CF が $33 \%$ の破壊形態となったが，このことは SB が弾性体である ために応力をある程度緩和できるため, TYPEI におい ても CF が表れたものと思われる.TYPE II では CFが $83 \% \mathrm{IF}$ が $17 \%$ となり $\mathrm{PE}$ と同様接着ジグにより曲げモ ーメントが減少したために CF の比率が上がったものと 考えられる、TYPE III, TYPE IV では, PE, SB ともす べての試験片において IF の破壊形態を示し, 破壊部の 安定性に伴い変動保数が低くなったと考えられる.すな わち，一般に同じ所で破壊する方が，毎回違う所で破壊 するよりも測定值が安定する9 。したがって破壊面の状 態からも, TYPE III, TYPE IV の変動係数が小さくなっ た原因が示唆された，また，接着の良否を接着効率 $\eta_{\mathrm{a}}$ から考えると, 引張接着効率 $\eta_{\mathrm{a}} \sigma$ とせん断接着効率の 斿てはつぎのように表すことができる10).

$$
\eta_{\mathrm{a}} \sigma=\sigma_{\mathrm{j}} / \sigma_{\mathrm{a}} \times 100(\%)
$$

$\sigma_{\mathrm{j}}:$ 引張接着強さ

$\sigma_{\mathrm{a}}:$ 接着剂自体の引張強さ

$$
\eta_{\mathrm{a}} \tau=\tau_{\mathrm{j}} / \tau_{\mathrm{a}} \times 100(\%)
$$

$\tau_{\mathrm{j}}:$ せん断接着強さ

$\tau_{\mathrm{a}}:$ 接着剂自体のせん断強さ

接着部が凝集破壊を生じる場合は接着剤自体が破壊す るのであるから，接着効率はほぼ 100\% となるが，界面 破壊の接着効率注 $100 \%$ 以下となる. 接着の良否の判定 や接着剂の物性を考察するには接着効率の良い凝集破壤 を生じる試験方法 (TYPE I, TYPE II) が適し, 界面に お汀接着効果や表面処理の効果を考察するには, 界面 破壊を生じ再現性の高い試験方法 (TYPE III, TYPE IV)
が適すると考える.TYPE I, TYPE II で両接着剤の接着 効率について比較すると, SB の方が凝集破壊率が良い ことがわかる.

\section{3. 表面処理の影響が接着強さに及ぼす影響}

接着系の破壊にはさまざまな破壊形態があるが，破壊 試験結果として現れる接着強さは，接着剤がある程度以 上の频集力を有していることと，接着剤と被着体の界面 に強い相互作用力があることにより発現する。そして凝 集破壊を起こす試験方法では接着強さはその接着剤が持 つ凝集力に依存するため, 測定結果から接着力を論ずる ことはできず，この場合接着強さを上げるには，接着凨 の強度（凝集力）を上げればよいだけである.一方，界 面破壊を起こす試験法では，接着強さは被着体と接着剂 の界面性状, 力学的性質に依存するために接着強さは接 着力の重要な因子となる．このように力学的性質につい ては, 界面破壊を起こす試験方法により一応の評価が可 能であるが，界面破壞においても接着強さを測定して界 面の相互作用力を測定したことにはならない，現状では 界面の相互作用力を直接測定する方法はないが，しかし 幸いなことに接触角（表面張力）は分子閒力の別の表現 であり，界面化学との別の接点を見出すことができる.

以上のような理由から, TYPE III の試験方法を採用し て表面処理の効果については接着強さの測定とともに, 同条件における接触角を調べ接着強さと界面の相互作用 力との関連についても検討した. 表面処理の影響を定性 的ならびに定量的に検討する目的で，実験 I と同一条件 にて繸 $20 \mathrm{~mm}$, 横 $10 \mathrm{~mm}$, 厚さ $2 \mathrm{~mm}$ の板状試験片を鋳 造作製した．定性的検討には，日立社製 560 型走查型電 子顕微鏡を用い, 電子顕微鏡写真を撮影した. 定量的検 討には, 東京精密社製表面粗さ, 形状測定器サーフコム $300 \mathrm{~B}$ を用い研磨方向に直角に中心線平均粗さ $(\mathrm{Ra})$ の 測定を行った. 接触角の測定は, PE の比重 1.90 と SB の比重 1.05 を利用して $0.05 \mathrm{~m} l$ の重量を電子天科上で

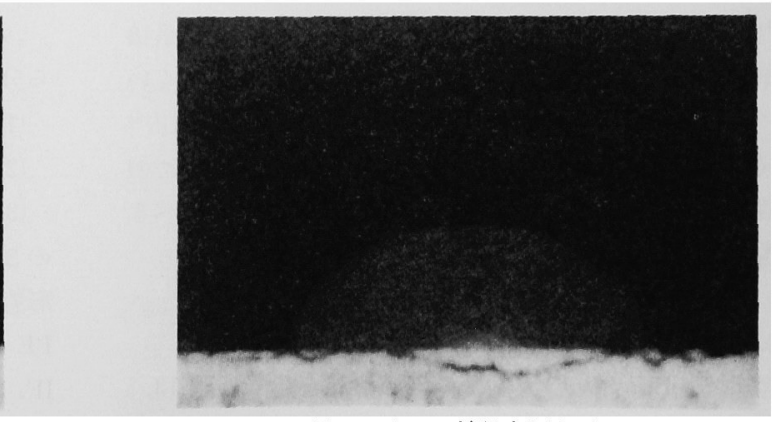

図 16 SB の接触角測定試料

(x)

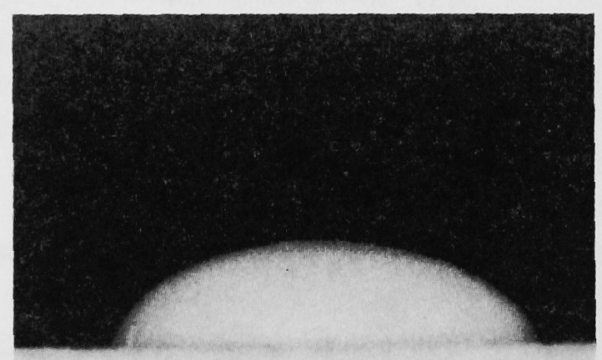

図 $15 \mathrm{PE}$ の接触角測定試料 
表 10 各種表面処理に対する接畕強さ, $\mathrm{Ra}$ ，接触角 $\left(\mathrm{kgf} / \mathrm{cm}^{2}, \mu \mathrm{m},{ }^{\circ}\right)$

\begin{tabular}{|c|c|c|c|c|c|}
\hline \multirow{2}{*}{\multicolumn{2}{|c|}{ 接着戍 }} & \multicolumn{4}{|c|}{ 表面処理 } \\
\hline & & $=600$ & サンドブラスト & 又不馣析 & シラン \\
\hline & $\mathrm{Ra}$ & $0.08 \quad(0.01)$ & $0.43 \quad(0.01)$ & $0.04(0.01)$ & $0.09(0.01)$ \\
\hline \multirow{2}{*}{ PE } & 接着強さ & $97(5.3)$ & $138(4.9)$ & $89(6.5)$ & $149(9.0)$ \\
\hline & 接触角 & $72(4.6)$ & $48(2.1)$ & $57(2.7)$ & $61(5.4)$ \\
\hline \multirow{2}{*}{$\mathrm{SB}$} & 接着強さ & $202(11.9)$ & $199(12.7)$ & $76(1.6)$ & $225 \quad(21.6)$ \\
\hline & 接触角 & $46(5.3)$ & $46(15.7)$ & $54(10.1)$ & $31(13.1)$ \\
\hline
\end{tabular}

検量しながら試験片に滴下し，それを水平方向から写真 撮影を行い，写真をトレースして接触角を計測した．図 15，16に PE と SB の接触角測定に用いた写真を示す. 測定はくり返し 3 回, 計 12 回行い平均值と標準偏 差を 求めた. 表 10 に測定値の平均值と標準偏差を示す.

表面粗さの接触角に対する影響には 2 種類あり, 数 $\mu \mathrm{m}$ までは Wenzel 型の効果を考虑し, $10 \mu \mathrm{m}$ 前後では Bartell 型に注意しなければならない11). 今回行った表 面処理の粗さは, スズ電析処理の $0.04 \mu \mathrm{m}$ からサンド ブラスト処理の $0.43 \mu \mathrm{m}$ の間にあり, Wenzel 型の影響 が接触角に作用していると考えられる．毛細管現象の式 を変形することにより Wenzel 型の次式が導かれる.

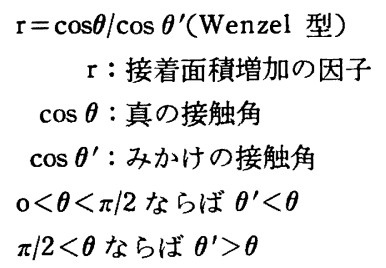

上記の式は，表面粗さが増大すればぬれ易い液体 $\left(\theta<90^{\circ}\right)$ の場合は一層ぬれ易くなり，ぬれ難い液体の場

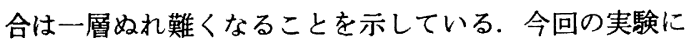
おける接触角の範囲は SB に対するシリコーター処理面 の $31^{\circ}$ から PE に対する \# 600 酎水研磨紙研磨面の $72^{\circ}$

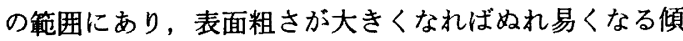
向にあると考えられる．実際の測定値においても，PE のスズ電析処理面と SB のシリコーター処理面を除い て, Wenzel 型の効果が認められた. 完全に表面粗さと 接着強さが一致しなかったのは，それぞれの接着凨中に 含まれる接着性モノマーの極性基が，表面処理に対して 特異的に配向するものを含むためと考える．また接触角 と接着強さの相関関係を調べた結果，SB においては相 関係数 $\mathrm{r}=-0.776$ となり, 接触角が小さくなるに伴い 接着強さが大きくなるという, 負の高度な相関が認めら れた. しかし，PE にはそのような相関関係は認められ
なかった，以上のことから，SB ではぬれ性の向上が接 着強さの向上に関与し，臨床においても好性を向上さ せる表面処理法が有効になると考える。一方 PE は，ぬ れ性が接着強さと直接関連しなかったことから，他の因 子との影響について今後検討する必要があろう。また接 触角と極性の関係については, $\theta=0 \sim 21^{\circ}$ は極性, $\theta=22$ $\sim 44^{\circ}$ はわずかに極性, $\theta=45 \sim 70^{\circ}$ はかなり非極性, $\theta=$ 71〜100 は非極性 ${ }^{22)}$ といわれているが，本研究において SB のシリコーター処理面が $31^{\circ} て ゙ ，$ 最もぬれが良くわ ずかに極性の状態であり，PEの

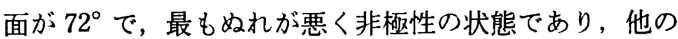
条件はこの間であるが，かなり非極性の状態である.

以上のように，接着剤に対する表面処理は特異的な反 応であり, 各種接着剤に有効な固有の表面処理を把握し ておく必要がある.

1） \#600 耐水研磨紙研磨面について

表面処理に対する基準面にアズ・キャストを用いた研 究がいくつか散見されるが，アズ・キャストの状態では 表面性状が粗造で, 鋳造時に生成した厚い酸化膜, ガス の吸着などにより，再現性が之しいために基準面として 用いるには不適当と思われる，そこで基準面には，実験 I と同一条件にて研磨, 洗浄を行った清浄面を採用し た. 今回基準面とした \#600 耐水研磨紙研磨面の表面粗 さ (Ra) は $0.08 \mu \mathrm{m}$ であり, $0.10 \mu \mathrm{m}$ 以下の凹凸は接触 角に影響を与えない12) といわれていることから，粗さ因 子 (roughness factor) の見地からは，基準面として採用 して良いと考えた. PE では平均值で $97 \mathrm{kgf} / \mathrm{cm}^{2}$ の接着 強さが得られたが，歯質に対する接着強さが 150〜200 $\mathrm{kgf} / \mathrm{cm}^{2}$ 得られている7)ことから，この表面処理では最 終的には接着剂と金属間からの破壊が考えられ強度不足 である。これは PE がコンポジットレジン系の接着剈で あり，フィラーの含有率が $70 \%$ と高く，その影響によ り接着モノマーのぬ机性が悪くなっているためと思われ る.またニッケルクロム合金の研磨面被膜の状態は， $\mathrm{X}$ 
$148-148$

表 11 スズ電析の因子と水準

\begin{tabular}{|c|c|c|c|c|}
\hline \multirow{2}{*}{ 因 } & \multirow{2}{*}{ 子 } & \multicolumn{3}{|c|}{ 水 } \\
\hline & & 1 & 2 & 3 \\
\hline \multicolumn{2}{|c|}{ C: : 電析条件 } & モード2 & モード 4 & モート゚ 6 \\
\hline
\end{tabular}

線光電子分光法 (ESCA) の観察によると, 下地からの 解析された電子線を乱さず，コバルトクロム合金と比較 すると被膜の状態は緻密でない13)．このような条件の被 膜に対して，PE の接着性モノマーが十分に作用できず， ぬれ性が悪くなり，その結果接着強さが低い值を示した ものと考えられる.

$\mathrm{SB}$ では平均值で $202 \mathrm{kgf} / \mathrm{cm}^{2}$ の高い接着強さが得ら れたが,これは SB の接着機構の1つであるカルボキシ ル基と酸化被膜表面に化学吸着された水の $\mathrm{OH}$ 基との水 素結合が強固な結合セグメント鈎 (anchor segment) と して働き，高い接着強さを示したものと思われる．接着

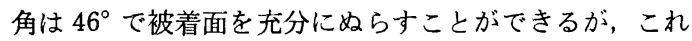
も上記の理由によるものと思われる。 また TBB 系は水 に接したところから重合を開始する特性があり，これが 接着系を形成するうえで有利に働き, 高い接着強さの発 現となったものと思われる.

2） $50 \mu \mathrm{m}$ サンドブラスト処理について

接着補綴を行うに際しサンドブラスト処理は，金属の 種類を問わず必須条件となっている.これはサンドブラ ス卜処理を行うことにより，金属表面に付着している有 機物の除去, 自然発生的な酸化物層 (さび) の除去, 表 面に吸着されたガスの除去, 表面の活性化, 被表面の拡 大などの効果が簡便にしかも確実に行われるからであ る.

PE において接着強さが向上したのは, 接触角が $72^{\circ}$ $\sim 48^{\circ}$ に変化しぬれ性が改善されたためと考える．ぬれ 性の改善は, サンドブラスティング後に生じるクレーマ 一効果 (エキソエレクトロン放電) により, 表面エネル ギーが増大し，PE の官能基と触媒的に作用して ${ }^{14}$ 表面 反応を起こし, その結果ぬれ性が改善されたものと思わ れる. そして細部までぬらされたにかわ線（gule line） の形成による被表面の拡大と，PEの特徽である大きな凝 集力によりアンカリングの効果が現れたと考えられる.

SB において接着強さの改善が認められなかったのは, 接触角に変化がなかったことから, SB にはサンドブラ ストが \#600 耐水研磨紙研磨面と同程度のぬれ性の改善 効果しかなかったためと思われる，つまり，表面処理が 同じであっても, 接着戍によって効果が異なる構造敏感
32 巻 1 号 (1988)

表 12 電析条件の測定値 $\left(\mathrm{kgf} / \mathrm{cm}^{2}\right)$

\begin{tabular}{cccc}
\hline \hline 電析条件 & モード 2 & モード 4 & モード 6 \\
\hline & 118 & 114 & 115 \\
接着強さ & 103 & 116 & 93 \\
& 86 & 110 & 114 \\
\hline
\end{tabular}

表 13 電析条件の分散分析表

\begin{tabular}{|c|c|c|c|c|}
\hline 因 & ss & df & $\mathrm{ms}$ & $F_{0}$ \\
\hline C : 電析条件 & 182 & 2 & 91 & 0.65 \\
\hline $\mathrm{e}$ & 840 & 6 & 140 & \\
\hline $\mathrm{T}$ & 1022 & 8 & & \\
\hline
\end{tabular}

性 (structure sensitive) の影響である。また,アンカリ ングの効果があったとしても，接着強さが大きいため や，凝集力が弱いために効果として現れにくかったこと が考えられる.

3） スズ電析処理について

表面処理法の 1 つにスズ電析処理があるが，これは通 常では不動態化しにくい金属表面にスズを電析すること により，スズの不動態化被膜と接着させる方法である. スズ電析装置にはクラエースを用いたが，この装置は $(+)$ 電極の金属容器の中に硫酸第一スズと安定剤を加 えた酸性浴で, 電流密度 $12 \sim 20 \mathrm{~A} / \mathrm{dm}^{2}$, 電圧 $6 \mathrm{~V}$ にて 電析を行うものである. 予備実験において, クラエース のモードを $2,4,6$ と変化させて電析を行い, PE を接着 させる一元配置による要因配置実験を行った結果, 差が 認められなかったので被膜の最も薄いと思われるモード 2 を選んで電析を行った. 表 11 亿因子と水準, 表 12 に 測定值, 表 13 に分散分析結果を示す.

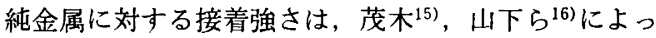
て報告されているが，スズはクロムと遜色ない高い接着 強さを示していることから, 被着体に対して適切な電析 が行われるならば，強い接着強さが期待できる.しかし， 本研究で行ったニッケルクロム合金に対する電析は $\mathrm{PE}$, $\mathrm{SB}$ ともに効果が認められなかった. 上記の原因を解明 するために, 試験後の破断面を観察したところ, 両接着 凨ともに接着剤側にほとんどの電析されたスズが残り， 一部は金属側に残留していたことから，スズに対する接 着剤の接着強さは十分であったが，合金に対するスズの 電析力が弱く電析層が WBL (week boundary layer) と なり凝集破壊したものと考える.電析力が弱くなった原 因として，電析されるスズと母合金は固溶体を作り易い 金属ほど電着性が良い17)が，スズとニッケルクロム合金 
を構成する元素において，原子の大きさ因子，電気化学 的因子, 価電子濃度が違うために固溶体を作りにくく ${ }^{18)}$, その結果電着性が悪くなったものと思われる.またニッ ケルクロム合金の被膜の安定性が電析を阻害したこと

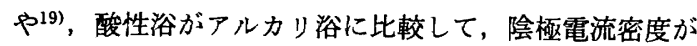
大きく密着性が悪いこと，また，酸性浴の最適電流密度 が $4 \sim 5 \mathrm{~A} / \mathrm{dm}^{2}$ である ${ }^{20)}$ のに対して，クラエースでは 12 $\sim 20 \mathrm{~A} / \mathrm{dm}^{2}$ と高く設定されていることから, 水素ガスの 電析層への吸蔵による水素ぜい性を起こし電析力が弱く なったと考えられる。

以上の理由により，本来貴金属合金用に開発されたク ラエースの電析条件が，ニッケルクロム合金に対しては 不利な条件として重複したために，効果が現れにくかっ たものと考えられる.

4）シランカップリング処理について

被着体表面のプライマー処理は, より確実な表面処理 法の1つであり，接着に適さない表面を，物理的または 化学的なエッチング法 (メリーランドブリッジ) ${ }^{21)}$ など に代わって，接着に適した表面へと改質する方法であ る. プライマー処理の目的は, 清浄な被着体 表 面の保 護, 接着剂と被着体との間の化学反応の促進, 親和性の 改善などがあり，工業界では広く用いられている．1\% 以下の添加量で，接着強さが 50 ～100\% 増加する 22 こと が知られているシランカップリング処理は，歯科界にお いても有効な表面処理法になると思われる. そこで今回 新しく開発された, シリコーターシステムによってシラ ンカップリング処理を用いた実験を行った.

シラン系接着促進鼡は, $\mathrm{RSiX}_{3}$ という式で表せる特殊 シリコン単量体で, $\mathrm{R}$ : 有機性反応基にはアミノ基, ビニ ル基, エポキシ基などがあり， $\mathrm{X}:$ 加水分解基にはアル コキシル基，八ロゲン基などがある．X：で示されるア ルコキシル基は加水分解されて水と反応してシラノール 基 $(\mathrm{SiOH})$ を生じ,ガラスまたは無機質表面と反応して シロキサン結合 (Si-O-Si) を形成するか, 表面の吸着水 と反応して水素結合を生じ, 無機質表面を有機化する ${ }^{23)}$.

シリコーターシステムは，まず金属表面にテトラエト キシシラン $\mathrm{Si}\left(\mathrm{OC}_{2} \mathrm{H}_{5}\right)_{4}$ を火炎分解蒸着させ, 金属表面 を下地の $\mathrm{SiOx}-\mathrm{C}$ 層で覆ってガラス化し，シロキサン結 合することにより化学結合を生じ，その結果疎水化され て耐久性に富む安定した界面が生じる. 次に $\mathrm{SiOx}-\mathrm{C}$ 層 を, メタクリロキシシラン $\mathrm{CH}_{2}=\mathrm{C}\left(\mathrm{CH}_{3}\right) \mathrm{COO}\left(\mathrm{CH}_{2}\right)_{3}$ $\mathrm{Si}\left(\mathrm{OH}_{3}\right)_{3}$ でカップリングすることにより表面を有機化 させ，金属と接着剤に化学結合による接着系を形成させ る.
PE において接触角が $61^{\circ}$ と大きくぬれが悪いにもか かわらず高い接着強さを示したのは，化学結合が接着系 に存在するためと思われる，ただし，ぬれが悪いことか ら，PE との相性があまり良くなく, シランカップリング 剤の適確な選択により, さらに高い接着強さの得られる 可能性が示唆された。

SB において，接触角が $31^{\circ}$ と非常に良いぬれ性を示 し，高い接着強さが得られたが，ぬれ性の改善程には高 い接着強さが得られていない。これは SB がシリコータ ーシステムに対する接着強さの限界值に達したか，ある いはぬれ性はひとつの尺度に過ぎないため，共有結合， イオン結合などの化学結合は，ぬれ性のみではとらえき れない面があるためと考える.

\section{V. 結 論}

2 種類の歯科用接着剂パナビア $\mathrm{EX}(\mathrm{PE})$ とスーパー ボンド C \& B (SB) を用いて, 4 種類の異なる形態につ いて接着試験を行ったときの接着強さを比較検討した. TYPE I, TYPE II の試験片は接着界面に垂直な応力の 加わる引張試験方法で, TYPE III, TYPE IV の試験片は 接着界面に平行な応力の加わる引抜き試験方法である. TYPE II, TYPE IV は JIS 6849 に規定されている引張 公差 $0^{\circ} 10^{\prime}$ 以内におさまるように接着ジグにより試験 片の作製を行った. その中から界面破壊を生じる TYPE IIIを用いて表面処理方法が接着強さに及ぼす効果につい て判定した．結果を要約すると次のようになる.

1. 接着強さの測定値は, PE を用いた場合 TYPEI が $89 \pm 19.2 \mathrm{kgf} / \mathrm{cm}^{2}$ と最小を示し, TYPE II が $139 \pm$ $23.9 \mathrm{kgf} / \mathrm{cm}^{2}$ と最大を示した. $\mathrm{SB}$ を用いた場合 TYPE II が $183 \pm 28.3 \mathrm{kgf} / \mathrm{cm}^{2}$ と最小を示し, TYPE IV が $363 \pm 11.3 \mathrm{kgf} / \mathrm{cm}^{2}$ と最大を示した.

2. 接着強さを変動係数（CV\%)で比較すると, $\mathrm{PE，}$ SB とも TYPE III, TYPE IV が小さくバラッキの少ない 試験方法である.

3. バラッキの少ない TYPE III, TYPE IV の破断面 はPE, SB とも界面破壊であった。

4. 界面破壊を生じる TYPE III を用いて表面処理の 効果を判定したところ，PE の接着強さはサンドブラス トやシランカップリングを用いると約 $50 \%$ 増加し， ス ズ電析による効果は認められなかった。

5. SB の接着強さは表面処理にサンドブラストやシ ランカップリングを用いても効果が認められず，スズ電 析で減少した. 
$150-150$

稿を終えるに臨み，終始ご想篤なるご指導，ご校閲を賜りまし た日本歯科大学新潟歯学部歯科理工学教室中村健吾教授に深甚 なる謝意を表します．また，本研究に種々のご助言を頂いた，日 本歯科大学付属歯科専門学校歯科技工士科尾崎順男部師に深謝 致します.さらに, 種々のご協力を頂きました日本歯科大学補経 学教室第 2 講座高橋英登証師ならびに日本歯科大学補緅学第 2 講座教室員諸兄に感謝の意を表します。

なお, 本論文の要旨は昭和 60 年度日本補緅歯科学会総会にて 発表した.

\section{文献}

1）長谷部伸一, 中村健吾 : 接着ブリッジ用 $\mathrm{Ni}-\mathrm{Cr}_{2}-\mathrm{Co}_{0}-\mathrm{Mo}_{0}$ 合 金の諸性質, 歯材器, $5: 773 \sim 790,1986$.

2）岩間英仁：貴金属と陶材の焼付強さ（第 1 報）焼付強さの 測定法, 歯理工誌, $14: 82 \sim 89,1973$.

3）金丸 競：新版接着と接着剂，102 103，大日本図書，東 京, 1976.

4) 高分子学会編: 接着と積層, $65 \sim 71$, 地人書館, 東京, 1965.

5）高分子学会編 : 接着一理論と応用, 254 268, 丸善, 東京, 1966.

6）杉村俊雄，池上皓三 : 二重重ね合わせ継手の引張せん断に よる変形と強度, 日本接着協会誌, $18: 102 \sim 109,1982$.

7）野口八九重, 越中 優, 中村かおり, 小園江芳之, 菊地敬 成：最新の歯質接着性セメントをテストする, $\mathrm{DE}, 69$ : $18 \sim 29,1984$.

8）熱田 充, 須尭 博, 田中卓男 : 接着ブリッジの維持力に 影響する因子について, 補緅誌, $28: 109 \sim 116,1984$.

9）宮入裕夫：構造用接着の理論と応用 (5), 接着, $14: 411$
32 巻 1 号 (1988)

$417,1970$.

10）日本接着協会編：接着ハンドブック第 2 版，580 584 , 日 刊工業新開社, 東京, 1982 .

11）酒井哲也：固体における “ぬれ” 挙動について，日本接着 協会誌, $18: 28 \sim 29,1985$.

12）芝崎一郎：接着百科 (下), 228 232, 高分子刊行会, 東京, 1985.

13）大野弘機，神澤康夫，川島 巧，山根由郎，相良昌宏： ESCA および反射電子解析によって解析された合金表面構 造と接着性レジンの接着強さの関係, 第 5 回日本歯科理工 学会学術講演会講演集 : $12 \sim 13,1985$.

14）日本金属学会編：界面物性, 222 223, 丸善, 東京, 1976.

15）茂木知治 : メタクリルレジン床用 $\mathrm{Co}-\mathrm{Cr}$ 合金の接着に関 する基礎的研究，4メタクリロキシエチルトリメット酸無 水物の効果, 補緅誌, $23: 660 \sim 676,1979$.

16）山下 敦, 近藤康弘, 藤田元英: 歯科接着性レジン・パナ ビア EXの歯科用合金に対する接着強さ その 2 貴金属 合金との接着について, 補緅誌, $28: 43 \sim 53,1984$.

17）大谷南海男 : 金属表面加工理論, 195, 填書店, 東京, 1968.

18）日本金属学会編：金属物性入門, 94 95, 丸善, 東京, 1977.

19）藤野武彦：メッキ技術入門, 2 19, 理工社, 東京, 1983 .

20）日本プレーティング協会編 : 現場技術者のための実用メッ キ (I) 増強版, $341 \sim 352$, 丸善, 東京, 1985 .

21) Livaditis, G.J. : Resin-bonded cast restration, clinical study, Int, J Perio and Rest Dent, $4: 71,1981$.

22）芝崎一郎: 接着百科 (下), $85 \sim 86$, 高分子刊行会, 東京, 1985.

23）吉岡 博: シランカップリング剤, 日本接着協会誌, 21 : $252 \sim 260,1985$. 